\title{
Low carbon scenarios for transport in India: Co-benefits analysis
}

\author{
Dhar, Subash; Shukla, P.R.
}

Published in:

Energy Policy

Link to article, DOI:

10.1016/j.enpol.2014.11.026

Publication date:

2015

Document Version

Peer reviewed version

Link back to DTU Orbit

Citation (APA):

Dhar, S., \& Shukla, P. R. (2015). Low carbon scenarios for transport in India: Co-benefits analysis. Energy Policy, 81, 186-198. https://doi.org/10.1016/j.enpol.2014.11.026

\section{General rights}

Copyright and moral rights for the publications made accessible in the public portal are retained by the authors and/or other copyright owners and it is a condition of accessing publications that users recognise and abide by the legal requirements associated with these rights.

- Users may download and print one copy of any publication from the public portal for the purpose of private study or research.

- You may not further distribute the material or use it for any profit-making activity or commercial gain

- You may freely distribute the URL identifying the publication in the public portal

If you believe that this document breaches copyright please contact us providing details, and we will remove access to the work immediately and investigate your claim. 


\title{
Low carbon scenarios for transport in India: Co-benefits Analysis
}

\author{
Subash Dhar ${ }^{1^{*}}$ and Priyadarshi R. Shukla ${ }^{2}$
}

1. UNEP Ris $\varnothing$ Centre, Technical University Denmark, Denmark

2. Indian Institute of Management, Ahmedabad, India

* Corresponding author email sudh@dtu.dk

Dependence on oil for transport is a concern for India's policymakers on three counts energy security, local environment and climate change. Rapid urbanisation and accompanying motorisation has created some of the most polluting cities in India and rising demand for oil is leading to higher imports, besides causing more $\mathrm{CO}_{2}$ emissions. The government of India wants to achieve the climate goals through a sustainability approach that simultaneously addresses other environment and developmental challenges. This paper analyses a sustainable low carbon transport (SLCT) scenario based on sustainable strategies for passenger and freight mobility, vehicle technologies and fuel using global $\mathrm{CO}_{2}$ prices that correspond to $2^{\circ} \mathrm{C}$ global stabilisation target. The scenarios span from years 2010 to 2050 and are analysed using the energy system model - ANSWER MARKAL. The SLCT scenario has improved energy security (cumulative oil demand lower by 3100 Mtoe), improved air quality (PM 2.5 emissions never exceed the existing levels) and the cumulative $\mathrm{CO}_{2}$ emissions are lower by 13 billion $\mathrm{CO}_{2}$ thereby showing that achieving development objectives with $\mathrm{CO}_{2}$ co-benefits is feasible.

Key Words : Transport Demand, $\mathrm{CO}_{2}$ Mitigation, Co-Benefits, Energy Security 


\section{Highlights :}

1) India's BAU transitions pose challenges for energy security and climate change.

2) Sustainable transport policies deliver benefits for air quality and energy security.

3) Sustainable transport policies fall short of mitigation needed for $2^{\circ} \mathrm{C}$ stabilization.

4) Transport sector becomes increasingly dependent on electricity.

5) Low carbon policies are essential to clean transport and electricity generation. 


\section{Introduction}

Transport sector globally is highly dependent on oil and India is no exception to this trend (IEA, 2013). High dependence on oil is a concern for India on account of three factors energy security, local environment and climate change. Energy security concerns arise due to a very high dependence on imports which create uncertainties for prices and supplies. In 2012 India imported $74.6 \%$ of oil and $37.5 \%$ of natural gas (BP, 2013). Rapid urbanisation and accompanying motorisation has created some of the most polluting cities in India. The top four cities globally, according to PM 2.5, were Delhi, Patna, Gwalior and Raipur from India and the top 100 cities had 33 from India (WHO, 2014). High levels of $\mathrm{PM}_{2.5}$ and $\mathrm{PM}_{10}$, much beyond national standard, is increasing morbidity (Guttikunda \& Jawahar, 2012). Fossil fuel combustion leads to $\mathrm{CO}_{2}$ emissions and around $14 \%$ of energy related $\mathrm{CO}_{2}$ emissions are attributable to transport sector (MoEF, 2010).

Transport sector energy use and emissions are also highly related to development patterns and investments in infrastructures. For example the per capita energy use for transportation between cities in US and those in developing Asia varies from more than $100 \mathrm{GJ}$ to less $10 \mathrm{GJ}$ and the main reason is their urban form and infrastructure priorities (Newman \& Kenworthy, 2011). Transport infrastructures account for a major part of infrastructure investments (Garg et. al., 2013) and therefore to achieve a low carbon transition it is important to direct the same in a direction which allows in achieving the climate and development goals through a sustainable approach (Gol, 2008).

Low carbon scenarios of transport sector for India have either been analysed for passenger transport (Singh, 2006; Reddy \& Balachandra, 2012) or provided in an aggregate fashion 
with no break up between passenger and freight transport (IEA, 2012, 2013). The low carbon scenarios also tend to focus only on improvements in efficiency of vehicles (Singh, 2006, IEA, 2012) and do not analyse the role of demand side measures for passenger and freight transport. This paper focuses on both passenger and freight transport and analyses both the demand side as well as supply side measures to draw policy recommendations.

\section{Characteristics of Indian transport system}

\subsection{Passenger Transport}

The per capita mobility in India for transport (excluding walking and cycling) has shown high correlation with per capita income (Figure 1) and is consistent with evidence from outside India (Small \& Dender, 2007; Schafer \& Victor, 2000). Increasing per capita mobility and an increasing population have combined to result in an increase in demand for passenger transport (Table 1) that has been faster than economic growth. The elasticity of passenger transport demand to GDP has been higher than 1, however come down from 1.64 for the period from 1950 to 1970 to 1.42 for the period 1990 to 2010 (NTDPC, 2014). The policies for passenger transport have mainly focused on motorised modes of transport and infrastructures for non-motorised modes such as walking and cycling have been ignored leading to a high share of accidents involving pedestrians and cyclists (Sundar \& Ghate, 2013). Walking and cycling is a dominant mode of transport within Indian cities (Tiwari, 2013) especially within weaker socio economic groups. There is no time series available for non-motorised transport officially however the same has been estimated at 220 billion pkm for 2010 using an average trip length of $1.6 \mathrm{~km}$ for walking and $3.9 \mathrm{~km}$ for cycling. Non- 
motorised transport catered to $25 \%$ pkms in 2010 out of a total demand of 892 billion pkms for urban transport.

Motorised passenger demand has been mainly met by road transport (two wheelers, buses and cars) within the cities and road, rail and air for intercity travel. Inside the cities, two wheelers have emerged as the largest mode of transport (estimated demand of around 256 billion pkm in 2010) due to sharp increase in ownership of two wheelers from $24.7 \%$ of households in 2001 to 35.2\% of households in 2011 (Census, 2012). Poor public transport within the cities and increasing size of cities has contributed to a growth of two wheelers. Rail transport has been steadily losing share of intercity passenger transport and had an $11 \%$ share of overall passenger demand in 2010 (Table 1). In the last decade air traffic has grown fastest amongst rail, road and air however the overall share of air is still less than $1 \%$ (Table 1).

\section{2. $\quad$ Freight Transport}

The per capita freight demand has been increasing at a fast pace (Figure 2) and is strongly linked to growing demand for commodities within economy e.g., growing demand for energy (Figure 2). The growth in demand for freight in the past has been faster than the GDP growth, elasticity of freight demand (only rail and road) to GDP since 1950 is estimated at 1.3. Elasticity to GDP has however reduced from 1.77 (for period 1950 to 1970) to 0.87 (for 1990-2004 period) (NTPDC, 2014).

Freight has been mainly transported by road and rail (Table 2 ) with road based freight taking the larger share of this demand. Since 2000 rail traffic growth has kept pace with road traffic 
to maintain share of rail in freight at around $40 \%$ (See Table 2). Coastal shipping and pipelines are the two other major modes of freight transport however no time series for tonne kilometres is available for them. A RITES study estimated freight transported through coastal shipping at 85.1 billion tkm and through pipelines at 105.5 billion tkm for 2007 (RITES, 2009). The growth in gross tonnage of coastal shipping (which can be taken as an indicator for coastal freight demand) has however been slower than both rail and road (Table 3, NTDPC, 2014). The government is however keen to increase the share of rail, a relatively energy efficient mode to road (Sims et. al., 2014) by increasing the investment for rail which are currently much lower than road (NTDPC, 2014).

\section{Methodology}

\subsection{Demand for Passenger Transport}

\subsubsection{Framework}

Transport sector accounts for the largest share of infrastructure investments. The share of infrastructure investments as a share of gross domestic capital formation have itself risen from $4.9 \%$ during $1995-99$ to $5.6 \%$ during $2007-11$ and share of transport sector of gross domestic capital formation has increased from $2 \%$ during $1995-99$ to $2.6 \%$ during $2007-11$ (Gol, 2012). Transport sector investments have long lives (25 to 100 years) and therefore can lead to lock ins and at the same time decisions are complex as besides travel effects lead to economic growth and externalities (Banister \& Berechman, 2001). Long term demand projection is therefore quite helpful in analysing long term strategies for transport. The passenger transport demand is estimated separately for urban and intercity as the strategies, institutional arrangements and technology options are different. The framework 
relies on a hybrid approach based on linking mobility to income (Schafer \& Victor, 2000) at the overall level, having foundation in transport economics, and more bottom up approaches at urban level related to trip frequency, trip lengths and modal choices, which have foundations in transport planning (Ewing \& Cervero, 2001).

The demand projections are done in a step wise fashion (Figure 3), first the overall demand is projected and then the same is divided into demand for urban and intercity transport. The modal split for both urban and inter-city demand is estimated next and follows the scenario storylines. The demand for private motorised modes is estimated first and linked to vehicle ownership and estimated using logistic regression. The unmet demand is considered to be fulfilled by public and para transit. The methodologies for each projection are described along with the input values in order to allow for a consistent projection across different scenario storylines.

\subsubsection{Overall Transport Demand}

The overall transport demand is estimated by the following identity.

$T D_{\text {overall }}=$ Population $\times$ Per Capita Mobility

The population projections till 2050 are taken as per the medium scenario for UN Population projections (UNPD, 2013). The per capita mobility for India in 2010 was less than $6000 \mathrm{~km}$ (Figure 1) and therefore at a relatively low level compared to developed countries (Newman \& Kenworthy, 2011, Millard-Ball \& Schiper, 2011). Per capita mobility tends to increase with per capita incomes (Schafer \& Victor, 2000) however empirical evidence is showing that per capita tends to peak between a per capita GDP of USD\$25,000 and US\$ 30,000 (e.g., both US Travel Survey (US-DoT, 2011) and UK Travel Survey (DoT-UK, 2013) 
show that per capita passenger demand has stabilised). This kind of phenomena can be represented by an S shaped curve which can be represented through different functional forms. The most common functional forms to represent such a process are the logistic and Gompertz functions (Singh, 2006). In this paper a logistic function is used. The saturation level has varied across countries from around 10,000 km per annum for Japan, around $12,000 \mathrm{~km}$ for EU countries (Singh, 2006) to a high of around $27,000 \mathrm{~km}$ per annum for US (Millard-Ball \& Schiper, 2011). The variations can arise due to demographic structure (e.g., Japan has a high proportion of old people in population who have limited mobility) to investment in infrastructure (e.g., US invested heavily into road infrastructures), to the design, diversity and density of cities (Cervero \& Kockelman, 1997; Ewing \& Cervero, 2010). India is having a large young population even in 2050 (working population would be 68\%) which can lead to a higher demand for mobility however the cities are dense and diverse now which can result in lower demand for transport from cities. The government is also planning to improve and speed up the connectivity between cities (NTDP, 2014) which can result in a higher demand for intercity travel. Therefore an asymptotic value of 20,000 has been taken for India.

\subsubsection{Urban Transport Demand}

There is a wide variation in modes used for transport in India. Public transport is inadequate in the small and medium sized cities (Pucher et. al., 2005) and results in low to almost zero modal shares for public transport (WSA, 2014). The function of public transport is generally performed by para transit modes (e.g., auto-rickshaws, cycle rickshaws, etc). Similarly walk trips are quite high in smaller cities however as the cities grow in size they decline (WSA, 2014). Therefore to understand the variation in travel characteristics across cities more 
systematically the cities were classified into 4 categories based on their population (Table 4).

The demand for urban transport was then calculated using equation 2 on the basis of trip rates and trip lengths which are considered different for different city categories (Table 5).

$T D_{\text {urban }}=\sum_{i=1}^{4} T R_{i} \times T L_{i} \times P o p_{i} \times 365$

$\begin{array}{lll}T D_{\text {urban }} & = & \text { Total Transport Demand from cities in a year } \\ T R_{i} & = & \text { Average Trip Rate (per day) in Category "i" cities } \\ T L_{i} & = & \text { Average Trip Length in Category "i" cities } \\ P \text { Pp }_{i} & = & \text { Aggregate population in Category "i" cities } \\ \mathrm{i} & = & \text { Category of city based on population }\end{array}$

The transitions across Indian cities in terms of trip rates and trip lengths have been covered comprehensively in two studies, RITES study carried in 1994 and a study carried by Wilbur Smith Associates (WSA) for 30 Indian cities in 2007. The average trip length tends to increase with the size of cities. The average trip lengths in WSA study vary from around 2 to $12 \mathrm{~km}$ with lower value corresponding to smaller cities and the higher value for larger cities. The trip lengths also vary with time (observed from difference in 1997 RITES study and 2007 WSA study) (WSA, 2014).The increase in trip lengths over time also coincide with increase in vehicle ownership and as higher vehicle ownerships are expected in future higher trip lengths are expected. 
The trip rates in Indian cities show an increase from smaller to larger cities with the overall trip rates varying from around 0.8 to 1.70 trips per day (WSA, 2014). A greater variation is for the motorised trip rates that vary from 0.3 to 1.1 trips per day (WSA, 2014). The trip rates are higher but stable in the developed countries, e.g., for UK average trip rate for 2012 was 2.66 trips per day (Do T-UK, 2013), for US average trip rate was 3.79 trips per day (Santos et. al., 2011). On the basis of above discussions following two heuristics were used to project future trip rates and trip lengths (Table 5)

a. Trip rates and trip length increased as city size increased

b. Trip rates and trip length increased with time as income increased

\subsection{Demand for Freight Transport}

Freight demand is closely correlated to demand of commodities within the economy. For example energy demand and freight demand show a high correlation (Figure 2). The consumption of commodities however follows a Kuznets curve i.e., increasing initially with increasing incomes however decline once the incomes cross a certain threshold (Canas et. al., 2003). In case of commodities like steel (Warell, 2014) and aluminium (Jaunky, 2012) a clear decline in per capita consumption has been observed in developed countries. These transformations however happen at a high level of per capita GDP e.g., US $\$ 24,289$ for steel (Warell, 2014). India has a per capita GDP of only US $\$ 1502$ in 2012 (WB, 2014) and even by 2050 the per capita GDP is projected to increase only by 11 times and therefore below the peak level. Estimation of coefficients is also not possible for the quadratic functions commonly used for depicting the Kuznets Curve using the short time series of consumption available in low income countries (Warell, 2014). Therefore a logistic curve to project the per capita freight demands was used. The asymptotic values is taken as $8000 \mathrm{tkm}$ which is 
closer to the level around which EU 28 freight values have peaked (See Figure 4). The overall transport demand for freight is estimated by the following identity.

$T D_{\text {overall freight }}=$ Population $\times$ Per Capita Freight

\subsection{Energy and Environment}

The different scenarios for passenger and freight demand have been analysed using the ANSWER MARKAL model. MARKAL is a mathematical model for evaluating the energy system and has a detailed characterisation of technology, fuel mix and investment decisions at detailed end-use level, while maintaining consistency with system constraints such as energy supply, demand, investment and emissions (Loulou et al., 2004). The ANSWER MARKAL model framework has been used extensively for India (Shukla et. al., 2008; Shukla et. al., 2009) and for the current paper the model has been improved by splitting demand for urban and intercity passenger transport, and improving the characterisation of vehicle technologies.

\section{Scenarios}

\subsection{BAU Storyline}

\subsubsection{Economic Growth}

The expectations about GDP growth rate of India vary though there is an agreement amongst different agencies that Indian economy will be one of the fastest growing economy in future (Chateau et. al.,2011, IEA, 2012 \& EIA,2013). Indian government assumes high growth rates of $8 \%$ and $9 \%$ for planning purposes (Gol, 2006). $8 \%$ growth scenario is the 
closest to the current dynamics at global, regional and local level and therefore designated as the base scenario around which we do analysis for the remaining scenarios. The GDP would grow more than 15 times between 2010 and 2050 at an average annual growth rate of $7.1 \%$. The contribution of sectors is also expected to witness a change with contribution of agriculture expected to go down further and be around 4\% of GDP by 2050. Transport sector contribution is expected to increase marginally from $5.6 \%$ in 2010 to $6.4 \%$ in 2050 .

\subsubsection{Demographic transition}

The population will continue to grow in the coming decades and is pegged to the medium variant projections from UN Populations division (UNPD, 2013). India's population will grow at a compounded average growth rate of $1.0 \%$ between 2010 and 2030, resulting in a population of 1.47 billion in 2030 and thereafter at a much slower $0.5 \%$ between 2030 and 2050 and reach 1.62 billion in 2050.

UN Projections show that India will continue to urbanise and by 2050 , India's urbanisation level will reach $52 \%$ (Figure 5), and its urban population of 0.87 billion will be the second largest in the world, after China (UNPD, 2013).

The household size has reduced in both rural and urban households; however, the trend is more evident in urban areas due to the growing nuclearisation of families (Census -India, 2012). The trend has been extrapolated (Table 6) by considering an asymptotic value of 2.5 per household which is the average household size in developed countries (US-DoT, 2011 for US and EC (2013) for EU ). 


\subsubsection{Passenger Transport Demand}

The per capita mobility is expected to increase from 5685 passenger kilometres in 2010 to 18837 in 2050 and consequently the overall demand for passenger transport is expected to increase from around 6962 billion pkm in 2010 to 31,872 billion pkm in 2050. The growth will be at a CAGR of 3.9\%, which is slower than GDP growth.

\subsubsection{Urban Passenger Transport Demand}

The demand for passenger transport would grow 6.6 times within the urban areas from 892 bpkm in 2010 to 5932 bpkm in 2050 in the BAU. The increased demand would be met through motorised modes - private (cars and two wheelers), public (metros, buses and auto rickshaws) and through walking and cycling. The demand met by private modes is linked to ownership of cars and 2 wheelers. Ownership of 2 wheelers is expected to increase from 127 per 1000 in 2010 to 330 per 1000 in 2050 whereas ownership of cars is expected to increase from 29 per 1000 in 2010 to 183 per 1000 in 2050. The residual demand is met by public and para transit.

The BAU scenario considers improvement in public transport within cities through better urban planning, building of metros, bus rapid transit systems and improvement of bus services. However financial and implementation constraints at city level limit the success of public transport and in the long run private transport will overtake public transport (Figure 6, Left Panel). 


\subsubsection{Intercity Passenger Demand}

The demand for intercity passenger transport is residual of the urban transport demand from overall passenger transport demand (Figure 3). Intercity passenger demand would increase by 4.3 times from 6772 bpkm in 2010 to 25941 bpkm in 2050 (Figure 7, Left Panel). The demand is mainly met by road based modes (cars, 2 wheelers and buses).

Rail based transport is less $\mathrm{CO}_{2}$ intensive relative to road based modes of transport (Sims et. al., 2014) and is also more flexible in terms of fuel options e.g., diesel, electricity, biofuels, etc. The government is planning to achieve a mode shift to rail by improving the attractiveness of rail by varied interventions, e.g.; by increasing travel speeds to enable maximum speed of $160-200 \mathrm{~km} / \mathrm{hr}$, introducing high speed train corridors and by improving coach services. The realization of these plans will however depend on increasing investments into rail infrastructures. NTDPC estimates investments on transport infrastructures would have to increase from $2.6 \%$ in 2011 to $3.7 \%$ of GDP by 2028 and for rail transport from $0.3 \%$ in 2011 to $1.2 \%$ by 2028 to bring it in parity with road infrastructures (NTDPC, 2014). In the past, even when Indian economy has grown at a robust GDP growth rate of more than $8 \%$, investments on transport infrastructures did not exceed $2.6 \%$, therefore in the BAU achievement of target investment is not expected. Rail investment is expected to keep pace with overall growth in transport demand and grow from 979 bpkm in 2010 to 3662 bpkm (Figure 7, Left Panel).

\subsubsection{Freight Transport Demand}

The per capita freight in BAU is expected to increase from 1464 tonne kilometres in 2010 to 5941 tonne kilometres in 2050 and consequently the overall demand for freight transport is 
expected to increase from around 1793 billion tkm in 2010 to 10,052 billion tkm in 2050 . The growth will be at a CAGR of $4.4 \%$, which is slower than GDP growth. Rail is expected to increase the mode share marginally from $35 \%$ in 2010 to $37 \%$ by 2050 and therefore road based transport would continue to have the largest share of freight transport (Figure 8, Left Panel). All natural gas, crude and bulk petroleum product transportation from 2030 onwards are expected through pipelines.

\subsection{Sustainable Low Carbon Transport (SLCT) Storyline}

In this paper four sustainability strategies for transport are analysed i) sustainable mobility for passenger transport ii) sustainable technologies iii) sustainable fuels and iv) sustainable logistics for freight. These alternative storylines are combined to create a sustainable low carbon transport (SLCT) scenario pegged to a global stabilisation target of 2 deg C. The $\mathrm{CO}_{2}$ price trajectory is assumed along a pathway which is aligned with more ambitious Copenhagen pledges which come into force post 2020. The $\mathrm{CO}_{2}$ price trajectory therefore is at a low level of 13.9 US $\$$ per $\mathrm{t} \mathrm{CO}_{2}$ in 2020 and then increases steadily to reach 200 US $\$$ per t $\mathrm{CO}_{2}$ by 2045 (Lucas et. al., 2013). Therefore though the transport sector is considering a number of sustainability actions the rest of economy is following a conventional path and therefore GDP growth and demographic transitions are same as the BAU.

\subsubsection{Sustainable Mobility}

\subsubsection{Urban Passenger Transport}

In the SLCT scenario reforms at city level ensures that cities have the financial resources and institutional capacities to maintain the share of public transport. A faster implementation of 
Metros and BRT systems along with a better integration with non-motorised transport modes and feeder buses is expected to improve share of both public transport and nonmotorised transport (Figure 6). It is assumed that by $205030 \%$ of private motorized demand of the BAU will shift to public transport. This shift is expected to result in a lower overall demand (430 bpkm in 2050) due to transit leverage (Newman et. al., 2008). Due to transit leverage for every $1 \mathrm{pkm}$ shift to public transport the demand for private transport is reduced by $4 \mathrm{pkm}$.

\subsubsection{Intercity Passenger Transport}

In case of SLCT scenario it is assumed that investment bottlenecks envisaged in BAU are overcome and the targeted investments into rail transport infrastructure are realised and therefore a major shift towards rail for intercity transport is realised. High Speed Corridors are built at a faster rate and maximum speed on all the remaining corridors is taken to 160$200 \mathrm{~km}$ per hr. All these raise the share of rail from $14.5 \%$ in 2010 to $30 \%$ in 2050 and by 2050 the railways will meet a demand of 7004 bpkm (Figure 7, Right Panel). The 30\% upper cap is considered as even in Japan where there is an extensive rail infrastructure including country wide network of high speed rail the modal share of rail has been around $27 \%$ (Tiwari \& Gulati, 2012).

\subsubsection{Sustainable logistics}

The SLCT scenario considered two interventions for freight i) a faster roll out of dedicated freight corridors ii) a reduced transportation of coal which is referred as coal by wire strategy. The combined impacts of these two strategies results in a reduction of demand 
and in 2050 the overall demand is lower by 774 btkm (Figure 8 ). The second impact is a mode shift towards rail, the share of rail freight increases to $48 \%$ by 2050 .

\subsubsection{Coal by wire}

Transportation of energy products (coal, oil and gas) is the largest commodity group transported and in 2010 a total of 822 million tonnes of coal, oil and gas were transported. The largest freight commodity for railways is coal and in 2010 a total of 268 billion tkm of coal was transported by rail (MoF, 2014) which accounts for $75 \%$ of coal transport. In the BAU the coal transportation by rail is expected to go up to 782 billion tkm by 2050 (Figure 9) and considers demand for coal in BAU to increase from 612 million tonnes in 2010 to 2509 million tonnes in $\mathbf{2 0 5 0}$ with largest demand for coal coming from power sector. The BAU has included different government policies which support renewables for power generation however since the overall demand for electricity is high coal continues to remain the mainstay of power generation. In the SLCT scenario there is a faster implementation of government policy of locating large coal based power plants near pit head or at coast. In this way coal transportation can be substituted by transportation of electricity or what has been referred to as coal by wire (Shukla et. al., 2009) and therefore share of rail in coal transportation is expected to come down to $20 \%$. The demand for transporting coal would therefore come down from 782 billion tkm to only 313 billion tkm (Figure 9).

\subsubsection{Dedicated Freight Corridors}

The policy makers in India want to restore the dominance of rail in freight transport (NTDPC, 2014). A big initiative in this direction is the dedicated freight corridors (DFC), which are to 
act as engine for industrial growth. In all 6 freight corridors are planned (Pangotra \& Shukla, 2012). In the BAU scenario institutional weakness and financial constraints are expected to slow down the implementation of these corridors however in SLCT scenario it is considered that institutional weaknesses and financial constraints are overcome to realise the full potential of DFC strategy and all 6 DFC are implemented and freight transported by DFCs increase from 461 billion tkm in 2016 to 2712 billion tkm in 2046 and of this freight around $76 \%$ is assumed to be from road transport according to RITES (Pangotra \& Shukla, 2012).

\subsubsection{Fuel Economy}

The government has announced fuel efficiency standards for cars which will come into force in 2017. These standards are linked to the weight of vehicles and the current trend for India is pointing towards an increase in average weight of vehicles. For example the average weight of cars sold increased from $987 \mathrm{~kg}$ in 2006 to 1037 in 2009 (BEE, 2011) and this increase in weights has also resulted in a slight deterioration of average fuel economy (Cuenot \& Fulton, 2011). The standards are expected to become more stringent with time (BEE, 2011). Therefore based on announced policy for cars an average fuel efficiency of 5 lit per $100 \mathrm{~km}$ in 2030 was set for BAU. The same was achieved by suitable constraints put on relatively inefficient car technologies. In the SLCT scenario a more stringent standard is considered which is linked to the vision set under the Global Fuel Economy Initiative of achieving an average fuel economy of 4 lit per $100 \mathrm{~km}$ in 2030 (Cuenot \& Fulton, 2011). 


\subsubsection{Fuel Switching}

Different vehicle technologies and fuel combinations defined (Table 7) in the model allowed analysis of fuel switching due to policies related to fuel economy and carbon prices. The policies related to biofuels and compressed natural gas (CNG) was however kept unchanged from the BAU. The government has a biofuel policy of $5 \%$ blending of ethanol in petrol in 20 states and 8 union territories. In 2010 the policy had achieved limited success around 2\% share of ethanol in petrol (Purohit \& Fisher, 2014). The policy involves price support for ethanol. A similar price support is also available for biodiesel however very limited success has been received for the same (Purohit \& Fisher, 2014). The BAU considered the continuation of price supports for ethanol and biodiesel. In SLCT biofuels get advantage due to a carbon price. CNG has emerged as a credible option where pipeline infrastructures have been made available in the cities (Dhar \& Shukla, 2010) and in 2010 around 4\% of energy demand for transport was met by CNG (IEA, 2013). In the BAU an expansion of gas infrastructures has been assumed. In the SLCT a high carbon price can help CNG in competition with petrol and diesel however put it at a disadvantage to biofuels and cleaner electricity.

\section{Results and Discussion}

\subsection{BAU Scenario}

\subsubsection{Energy Demand}

The demand for energy in BAU will increase by around 6 times from 58 Mtoe in 2010 to 337 Mtoe in 2050 at a CAGR of $4.6 \%$. The CAGR is higher than growth in demand for both 
passenger transport (3.9\%) and freight transport (4.4\%) which means that energy intensity of transport sector would be higher in future. The fuel choices get diversified however the dependence on oil is expected to continue in the BAU and demand for oil increases to 258 Mtoe by 2050 (Figure 10). Alternative fuel like CNG and bio fuels are expected to play an increasing role. Electricity is also expected to play an increasing role due to increasing share of electricity within railways, in metro and other rail based systems within the cities and due to electrification of vehicles for road transport. The share of electricity in meeting transport demand is however higher than what is reflected in the share of energy since electric vehicles are more efficient.

\subsection{2. $\mathrm{CO}_{2}$ Emissions}

The $\mathrm{CO}_{2}$ emissions from transport in $\mathrm{BAU}$ would increase by around 5.5 times from 2010 to 1092 Million t $\mathrm{CO}_{2}$ in 2050 (Figure 11) and this includes embedded emissions in electricity. The energy demand and $\mathrm{CO}_{2}$ emissions show a minor decoupling on account of the diversification of fuel mix towards CNG and biofuels (Figure 10). Cleaning of electricity also contributes as the $\mathrm{CO}_{2}$ intensity of the grid reduces from 0.80 Million t $\mathrm{CO}_{2}$ per Gwh in 2010 (CEA, 2012) to 0.64 Million t $\mathrm{CO}_{2}$ per GWh in 2050.

\subsubsection{Local Pollutants}

PM 2.5 is one of the key local pollutants and is responsible for severe health risks. A study in six Indian cities found transport sector accounts for $30 \%-50 \%$ of the PM 2.5 (Guttikunda \& Mohan, 2014). In India Bharat Stage III (BS III) emission standard for motor vehicle (equivalent to Euro III) are applicable across India and BS IV emission standards are in vogue 
in the National Capital Region of Delhi and 20 other larger cities. An additional 30 cities are planned to move to Euro IV by 2015 (Gol, 2014). In the BAU it is assumed that the BS IV would be fully implemented by 2020 all across India in line with roadmap proposed in Auto Fuel Vision and Policy 2025 (Gol, 2014). BS IV emission standards are much stricter compared to the BS III e.g., for Light duty vehicles with a mass of less than $2500 \mathrm{~kg}$ the PM emissions come down from $50 \mathrm{mg}$ per $\mathrm{km}$ to $25 \mathrm{mg}$ per $\mathrm{km}$. In cases of buses and trucks the reductions are even steeper. Therefore due to enforcement of BS IV emission norms PM 2.5 shows a moderate increase from 2010 (Figure 12) despite an increase in VKTs for cars by $129 \%$ and $115 \%$ for two wheelers. In the BAU a further tightening of emission norms (BS V all across India by 2025) ensure that despite increase in vehicles the PM 2.5 emissions come down from 2020 levels. In 2040 a steep reduction in PM 2.5 emissions is observed which besides stricter emission standards is due to a larger diffusion of electric vehicles both within cars and two wheelers.

\subsection{SLCT Scenario}

\subsubsection{Energy Demand}

In SLCT scenario, due to the strategies related to passenger mobility, logistics, and fuel economy the demand for energy from transport comes down to nearly half of what is in the BAU by 2050 (Figure 10, Right Panel). The cumulative savings from 2010 to 2050 for oil demand would be around 3100 Mtoe and at a price of US $\$ 100$ per barrel of oil would be equivalent to $0.53 \%$ of cumulative GDP. The energy mix also diversifies and by 2050 around $60 \%$ of energy would be from alternative fuels (biofuels, electricity, hydrogen and CNG). 


\subsubsection{Wedges for $\mathrm{CO}_{2}$ Mitigation}

Transport sector can transit to a pathway consistent with the 2 deg C scenario and there are five main wedges which can deliver the reductions in $\mathrm{CO}_{2}$ emissions (Figure 13). The first wedge is sustainable mobility for passenger transport and the reductions between 2010 and 2050 are equivalent to 2104 Million $\mathrm{t} \mathrm{CO}_{2}$. The second wedge is related to sustainable freight and the same can provide an additional 675 Million t $\mathrm{CO}_{2}$. The third wedge of fuel economy of vehicles can provide a reduction of 4100 Million $\mathrm{C}_{2}$. The fourth wedge of bio fuels can provide a small but significant reduction of 797 million $t \mathrm{CO}_{2}$. The fifth and the largest wedge of electricity cleaning are linked to a wider diffusion of electric vehicles (cars, two wheelers, buses and rail based modes) and decarbonisation of electricity. The high carbon price in the SLCT scenario results in cleaning of electricity due to a higher share of renewables, natural gas and coal based capacities with CCS. The $\mathrm{CO}_{2}$ intensity of electricity is only 0.06 Million $\mathrm{tCO}_{2}$ per GWh in 2050.

\subsubsection{Local Pollutants}

PM 2.5 emissions under the SLCT scenario never increase beyond the 2010 levels and this would mean an improvement in air quality in cities since the emissions within cities would happen over a larger area (due to increase in size and number of cities). The scenario did not consider any additional emission standards therefore the further reduction in PM 2.5 (and by extension for other pollutants) is due to three factors - reduction in demand for private transport modes i.e., cars and two wheelers (Figure 6) in cities and road transport for intercity (Figure 7), improvement in efficiency of vehicles and higher diffusion of electric vehicles (Figure 10). 


\section{Conclusions and Policy Implications}

India's National Action Plan on Climate Change (NAPCC) proposes to achieve low carbon transition through a sustainability approach that simultaneously addresses other environment and developmental challenges. We find that the transport sector actions that moderate demand for passenger and freight transport, shift demand to more sustainable modes, improve efficiency of vehicle technologies and shift to cleaner fuels will address concerns of policy makers for energy security and local environmental issues and, also deliver the climate co-benefits due to reduced carbon intensity of transport sector. However, these climate co-benefits are relatively small when compared to the level of mitigation needed for the 2 degree $\mathrm{C}$ stabilization target.

Our modelling assessment shows that although the efficiency of the vehicle fleet do keep improving under the BAU policy dynamics ; the rapidly rising transport demand, driven by increasing population, urbanization and income, tends to overwhelm the energy savings from efficiency improvements. The oil demand under BAU keeps rising to fuel the motorized vehicles. This has three adverse consequences: i) rising air pollution in the cities, ii) enhanced energy security risks, since India is a net oil importer and will remain so in the future under the BAU scenario, and iii) rising carbon emissions from the transport sector, including the indirect carbon emissions from the electricity use.

India's policymakers have targeted to address these concerns via varied interventions such as the periodic appointment committees such as Auto-fuel Policy Committee (Gol, 2002; 
Gol, 2014) that recommend the fuel and vehicle emissions norms, fuel economy standards (BEE, 2011); and the overarching programs like the 'Sustainable Habitat' mission announced under the India's NAPCC. These transport policy interventions fall under two distinct areas: i) the measures aimed at ameliorating impacts on national and regional sustainability indicators, and ii) the measures that contribute to global commitments like climate change. In the context of transport policies, the first set of measures are covered under the 'sustainability' theme and the second set of measures are included under the 'low carbon development' theme. The sustainable low carbon transport (SLCT) scenario assessed in this paper includes policies aiming to reverse the adverse trends of energy security, air pollution and carbon emissions observed in the BAU.

The policies aimed to achieve sustainable low carbon transport scenario may complement or contradict vis-à-vis achieving the aims of each of the two distinct themes of sustainability and climate change. The enhanced fuel economy of transport vehicle fleet, for example, is complementary as it ameliorates energy security, air pollution as well as carbon emissions. Conversely, for instance, the carbon emissions limitation reduces carbon emission and air pollution but increases energy security risks due to substitution of domestic coal by imported gas to generate electricity used by electric vehicles. The key issue in preparing the policy package for SLCT is to align the sustainability and climate change policies to gain multiple co-benefits and thereby optimize the overall benefits. 
Our SLCT scenario assessment, to begin with, bifurcate the policies aimed at two themes. The sustainable transport measures; e.g.: i) fuel economy standards, ii) end-of-pipe air pollution measures, such as introduction of Euro-series equivalent emissions norms, and iii) fuel substitution, such as $10 \%$ ethanol blend or the use of gas as a fuel to replace liquid fuels in cars; deliver substantial national energy security and urban air pollution benefits. But, these sustainability measures notwithstanding, in the absence of carbon mitigation commitment, India's transport sector would remain carbon intensive due to continued predominance of fossil fuel in road transport vehicles and coal intensive electricity supply in the electricity grid.

In India's national sustainable development agenda, the air quality is a key policy concern now as a large number of cities has way beyond national ambient air quality standards. Our modelling assessment shows that in the BAU, PM 2.5 emissions (a key local pollutant) from transport would peak by 2020 , due to stricter emission standards and decline thereafter. Under BAU, it would still take longer to bring PM 2.5 concentration within desirable norms in the cities. In the SLCT though, the PM 2.5 emissions would find sustained decline from the current levels and the PM 2.5 concentrations in the cities would improve at a quicker pace than under the BAU scenario. Thus the carbon limitation assumed under SLCT can deliver major improvements for air quality.

Typically, transport sector's response to short-term price shocks is relatively inelastic due to high inertia of infrastructures, technologies and behaviours. Our modelling analysis shows that the long-term carbon price expectations, which correspond to achieving global 2 degree $C$ stabilization target by the year 2100 , would substantially alter the infrastructures 
and technology choices in India over the next several decades. The relative change in fuel prices due to carbon price leads to technology and fuel choices that deliver better fuel economy and lower carbon emissions. The altered choices like electric vehicles and low carbon electricity, higher share of mass transport and shift to non-motorized transport deliver substantial energy security and air pollution co-benefits.

Three conclusions from our modelling assessment are as under:

1) India's national sustainable transport policies do ameliorate air quality in the shortterm and energy security in the medium-term, however their impact on carbon emissions is far short of mitigation needed for low carbon transition needed to respond to global emissions limitations consistent with $2^{\circ} \mathrm{C}$ stabilization target.

2) Targeted low carbon policies are therefore essential to decarbonize India's transport. To generalize, a similar conclusion could also be valid for other countries, e.g. China, where electricity generation is expected to remain carbon intensive in absence of significant carbon emissions limitations.

3) Low carbon transport policies, e.g. global carbon price trajectory to achieve $2^{\circ} \mathrm{C}$ stabilization target, delivers positive co-benefits, e.g. vis-à-vis air quality, or negative co-benefits (or co-costs), e.g. vis-à-vis energy security in India due to the substitution of domestic coal by imported gas.

These conclusion from the low carbon transport modelling assessment for India suggests that substantial co-benefits can be gained by aligning the policies and actions delineated for national sustainable transport which aims to garner national benefits and low carbon 
transport which aims to contribute to the global climate stabilization target. This would require recognizing that across national and global domains there is: i) asymmetry in the amounts of co-benefits, ii) complementarity of co-benefits, iii) contrasting co-benefits and co-costs, and iv) difference in the timing of the benefits. The sustainable low carbon transport policy architecture that can align the policies and actions across time (i.e. short-term to long-term) and space (local to global) therefore can deliver substantial positive co-benefits. The key interventions in the short-run have to avert getting into lock-ins such as in infrastructures engendering high energy and emissions paths. Coordination of transport actions that deliver national and global co-benefits is often more complex due to coordination constraints. Our assessment for India's transport sector shows that, such constraints notwithstanding, it is possible to gain substantial cobenefits by aligning the national sustainable transport policies and actions with the economic signals from the global climate change regime. The formal integrated assessments, as we show, would help to untie the 'Gordian knot' that creates long-term adverse lock-in of the national transport sector.

\section{Acknowledgements:}

The research for this paper was supported from UNEP project "Promoting Low Carbon Transport in India" which was funded by the German government (BMU) under the International Climate Initiative 


\section{References}

Banister, D., Berechman, Y. 2001. Transport investment and the promotion of economic growth. Journal of Transport Geography: Mobility and Spatial Dynamics, 9, 209-218

BEE, 2011. Consultation Paper. Bureau of Energy Efficiency

<http://beeindia.in/schemes/documents/s\&l/CONSULTATION/> Accessed on $17 \mathrm{Apr}$ 2013

BP, 2013. BP Statistical Review of World Energy June 2013. BP <http://www.bp.com/statisticalreview> Accessed on 11 June 2014

Canas, A, Ferrao, P, Conceicao, P, 2003. A new environmental Kuznets curve? Relationship between direct material input and income per capita: evidence from industrialised countries. Ecological Economics. 46, 217-229

CEA, 2012 Baseline Carbon dioxide Emissions from Power Sector Version 7.0. Central Electricity Authority (CEA) < http://www.cea.nic.in/> Accessed on 26th November 2013

Census-India, 2012. Census of India-2011, Census of India, Government of India

Cervero, R., Kockelman, K., 1997. Travel demand and the 3Ds: Density, diversity, and design. Transportation Research Part D: Transport and Environment 2,199-219

Chateau, J., Rebolledo, C., Dellink, R., 2011. An Economic Projection to 2050: The OECD "ENV-Linkages" Model Baseline", OECD Environment Working Papers, No. 41, OECD Publishing. <http://dx.doi.org/10.1787/5kg0ndkjvfhf-en > Accessed on 26th November 2013

Cuenot, F., Fulton, L., 2011. International comparison of light-duty vehicle fuel economy and related characteristics, OECD/IEA, Paris

Dhar, S., Shukla P.R., 2010. Natural Gas Markets in India: Evolution and Future Scenarios, Vol. McGraw Hill, New Delhi

DoT-UK, 2013. National Travel Survey: 2012, Department of Transport, Government of UK (DoT-UK), <https://www.gov.uk/government/uploads/system/uploads/attachment data/file/243957/ nts2012-01.pdf > Accessed on 26 Feb 2014

EC, 2013. Database : Population. Eurostat, Europeon Commission <http://epp.eurostat.ec.europa.eu/portal/page/portal/population/data/database> Accessed on 17 May 2014

EEA, 2013. Freight transport demand (CSI 036/TERM 013) - Assessment published Dec 2013. Europeon Environment Agency, <http://www.eea.europa.eu/data-andmaps/indicators/freight-transport-demand-version-2/assessment-3> Accessed on 17 May 2014 
EIA, 2013. International Energy Outlook 2013. US Energy Information Administration (EIA), <http://www.eia.gov/forecasts/ieo/world.cfm> Accessed on 17 Feb 2014

Ewing, R., Cervero, R., 2001. Travel and the built environment: A synthesis. Transportation Research Record 87-113

Ewing, R., Cervero, R., 2010. Travel and the Built Environment. Journal of the American Planning Association 76, 265-294

Garg, A., Naswa, P., Shukla, P.R., 2013. Impact Assessment and Management: Framework for Infrastructure Assets: A Case of Konkan Railways, UNEP Risoe Centre, Roskilde

Gol, 2002. Auto Fuel Policy Report (August 2002), Government of India, New Delhi

Gol, 2008. National Action Plan on Climate Change. Government of India, Prime Minister'sCouncil on Climate Change, <http://www.pmindia.nic.in/Pg01-52.pdf> Accessed on 18th May 09

Gol, 2012. National Transport Development Policy Committee: Interim Report. Government of India (Gol), Planning Commission, April 2012, <http://www.cris.org.in/NTDPCWEB/ > Accessed on $11 \mathrm{Jul} 2014$

Gol, 2014. Auto Fuel Vision and Policy 2025: Report of the Expert Committee, Planning Commission, Government of India (Gol), New Delhi <http://petroleum.nic.in/autopol.pdf> Accessed on $11 \mathrm{Jul} 2014$

Guttikunda, S.K., Jawahar, P. 2012. Application of SIM-air modeling tools to assess air quality in Indian cities. Atmospheric Environment 62,551-561

Guttikunda S.K., Mohan, D. 2014. Re-fueling road transport for better air quality in India. Energy Policy 68,556-561

IEA, 2012. World Energy Outlook 2012, Vol. OECD/IEA, Paris

IEA, 2013. World Energy Outlook 2013, Vol. OECD/IEA, Paris

Jaunky, V.C., 2012. Is there a material Kuznets curve for aluminium? evidence from rich countries. Resources Policy 37, 296-307

Loulou, R., Goldstein, G., Noble, K., 2004. Documentation for the MARKAL Family of Models, October 2004. <http://www.etsap.org/documentation.asp> Accessed on 13th September 2007

Millard-Ball, A., Schipper, L., 2010. Are We Reaching Peak Travel? Trends in Passenger Transport in Eight Industrialized Countries. Transport Reviews 31,357-378

MoEF, 2010. India: Green House Gas Emissions 2007, Indian Network for Climate Change Assessment (INCCA), Ministry of Environment and Forests (MoEF), Government of India , New Delhi <http://moef.nic.in/downloads/public-information/Report INCCA.pdf> Accessed on 13 September 2013 
MoR, 2012. Annual Report \& Accounts: 2011-12, Ministry of Railways (MoR), Government of India, New Delhi $<$ http://www.indianrailways.gov.in/railwayboard/view_section.jsp?lang=0\&id=0,1,304,366, $554,1279>$ Accessed on 28 Apr 2014

MoF (2014) Economic Survey 2013-14, Ministry of Finance (MoF), Government of India <http://indiabudget.nic.in/survey.asp> Accessed on 03 October 2014, New Delhi

Newman, P., Kenworthy, J., 2011. Evaluating the Transport Sector's Contribution to Greenhouse Gas Emissions and Energy Consumption. In: Salter R, Dhar S, Newman P (eds) Technologies for Climate Change Mitigation: Transport Sector. UNEP Risoe Centre, Roskilde <http://www.tech-action.org/guidebooks.asp>, Accessed on 21 September 2012

Newman, P., Kenworthy, J., Glazebrook, G., 2008. How to create exponential decline in car use in Australian cities. Australian planner 45,17-19

NTDPC, 2014. India Transport Report: Moving India to 2032, National Transport Development Policy Committee, Planning Commission, Government of India, New Delhi $<$ http://planningcommission.nic.in/sectors/index.php?sectors=National\%20Transport\%20D evelopment\%20Policy\%20Committee\%20(NTDPC)> Accessed on 22 Apr 2014

Pangotra, P., Shukla, P.R., 2012. Infrastructure for Low Carbon Transport in India: A Case Study of Delhi-Mumbai Dedicated Freight Corridor, UNEP Risoe Centre, Roskilde

Pucher, J., Korattyswaropam, N., Mittal, N., Ittyerah, N., 2005. Urban transport crisis in India. Transport Policy 12,185-198

Purohit, P., Fischer D.G., 2014. Second-generation biofuel potential in India: Sustainability and Cost Considerations, Vol. UNEP Risoe Centre on Energy, Climate and Sustainable Development, Technical University of Denmark

Reddy, B.S., Balachandra, P., 2012. Urban mobility: A comparative analysis of megacities of India. Transport Policy 21,152-164

RITES, 2009. Total Transport System Study on Traffic Flows and Modal Costs. Planning Commission, Government of India, New Delhi

Santos, A., McGuckin, N., Nakamoto, H.Y., Gray, D., Liss, S., 2011. Summary of Travel Trends: 2009 National Household Travel Survey, U.S. Department of Transportation, <http://nhts.ornl.gov/2009/pub/stt.pdf> ,Accessed on 26 Feb 2014

Schafer, A., Victor, D.G., 2000. The future mobility of the world population. Transportation Research Part A: Policy and Practice 34,171-205

Shukla, P.R., Dhar, S., Victor D.G., Jackson, M. 2009. Assessment of demand for natural gas from the electricity sector in India. Energy Policy 37,3520-3535

Sims R, Schaeffer R, Creutzig F, Nunez XC, D Agosto M, Dimitriu D, Meza MJF, Fulton L, Kobayashi S, Lah O, McKinnon A, Newman P, Ouyang M, Schauer JJ, Sperling D, Tiwari G, 
Amekudzi AA, Borba BSMC, Chum H, Crist P, Hao H, Helfrich J, Thomas Longden A, Lucena FPd, Peeters P, Plevin R, Plotkin S, Sausen R (2014) Chapter 8 : Transport. In: IPCC, WG III, AR5

Singh, S.K., 2006. Future mobility in India: Implications for energy demand and $\mathrm{CO}_{2}$ emission. Transport Policy, 13,398-412

Small K.A., Dender, K.V. 2007. Long Run Trends in Transport Demand, Fuel Price Elasticities, and Implication of Oil Outlook for Transport Policy. Joint Transport Research Centre, Paris, OECD and International Transport Forum <http://www.oecd-ilibrary.org/transport/long-runtrends-in-transport-demand-fuel-price-elasticities-and-implications-of-the-oil-outlook-fortransport-policy_234582117245> Accessed on 3 Oct 2014

Sundar S, Ghate A.T. 2013. Accidents and Road Safety: Not High on the Government's Agenda. Economic \& Political Weekly XLVIII, 77-83

Transport Do 2013. National Travel Survey: 2012, Department of Transport, Government of UK,

<https://www.gov.uk/government/uploads/system/uploads/attachment_data/file/243957/ nts2012-01.pdf> Accessed on 26 Feb 2014

Tiwari, G., 2013. Metro Rail and the City: Derailing Public Transport. Economic \& Political Weekly XLVIII, 65-76

Tiwari, P., Gulati, M. 2013. An analysis of trends in passenger and freight transport energy consumption in India. Research in Transportation Economics: Special Is: Economics of Sustainable Transport in India 38,84-90

UNPD, 2013. The World Population Prospects: The 2012 Revision. United Nations Population Division (UNPD). $<$ http://esa.un.org/wpp/unpp/panel population.htm $>$ Accessed on 23rd Dec 2013

US-DoT, 2011. Summary of Travel Trends: 2009 National Household Travel Survey. US Department of Transportation, Bureau of Transportation Statistics

US-DoT, 2014. National Transportation Statistics, Table 1.49 Tonne Miles of Freight (Updated January 2014). US Department of Transportation, Bureau of Transportation Statistics

<http://www.rita.dot.gov/bts/sites/rita.dot.gov.bts/files/publications/national_transportati on_statistics/index.html\#chapter_1> Accessed on 17 May 2014

Wårell, L., 2014. Trends and developments in long-term steel demand : The intensity-of-use hypothesis revisited. Resources Policy 39,134-143

WHO (2014) Ambient (outdoor) air pollution database, by country and city. World Health Organization, Geneva, Switzerland <http://www.who.int/phe/health_topics/outdoorair/databases/cities/en/> Accessed 01 October 2014. 
WSA, 2014. Traffic and Transportation Policies and Strategies for Urban Areas. Presentation by Wilbur Smith Associates (WSA) to Working Group on Urban Transport, Available at $<$ http://www.cris.org.in/NTDPC_Discussion_Forum/PublicPages/innerpage1.jsp?ActiveMen $\mathrm{u}=\mathrm{WG} \&$ contentMenu=RP $>$ Accessed on 28 Feb 2014 
Table 1. Trend in motorised passenger transport demand (Billion PKM)

\begin{tabular}{|cccccccc|}
\hline Year & Rail & \multicolumn{3}{c}{ Road } & \multicolumn{2}{c|}{ Air $^{1}$} & Total \\
& Billion PKM & $\begin{array}{l}\text { \% } \\
\text { Share }\end{array}$ & Billion PKM & $\begin{array}{l}\text { \% } \\
\text { Share }\end{array}$ & Billion PKM & $\begin{array}{l}\text { \% } \\
\text { Share }\end{array}$ & Billion PKM \\
\hline $\mathbf{1 9 7 0}$ & 118 & $41 \%$ & 169 & $59 \%$ & 2 & $0.5 \%$ & 289 \\
\hline $\mathbf{1 9 8 0}$ & 209 & $37 \%$ & 353 & $62 \%$ & 4 & $0.8 \%$ & 566 \\
\hline $\mathbf{1 9 9 0}$ & 296 & $19 \%$ & 1257 & $81 \%$ & 7 & $0.5 \%$ & 1560 \\
\hline $\mathbf{2 0 0 0}$ & 457 & $18 \%$ & 2097 & $82 \%$ & 12 & $0.5 \%$ & 2567 \\
\hline $\mathbf{2 0 0 5}$ & 616 & $13 \%$ & 4252 & $87 \%$ & 24 & $0.5 \%$ & 4891 \\
\hline $\mathbf{2 0 1 0}$ & 979 & $11 \%$ & 5940 & $88 \%$ & $48^{2}$ & $0.6 \%$ & 6966 \\
\hline CAGR 1970-2010 & $\mathbf{5 . 4 3 \%}$ & & $\mathbf{9 . 9 6 \%}$ & & $\mathbf{8 . 9 4 \%}$ & & $\mathbf{8 . 2 8 \%}$ \\
\hline CAGR 1990-2010 & $\mathbf{6 . 1 7 \%}$ & & $\mathbf{8 . 0 7} \%$ & & $\mathbf{1 0 . 0 3} \%$ & & $\mathbf{7 . 7 7 \%}$ \\
\hline
\end{tabular}

${ }^{1}$ Only Domestic Air Travel

${ }^{2}$ extrapolation done by Author

Data Source: Annual Reports, Rail: Ministry of Railways, Road: Ministry of Road Transport and Highways, Air: Ministry of Civil Aviation.

Table 2. Trend in freight transport demand (Billion TKM)

\begin{tabular}{|cccccc|}
\hline Year & $\begin{array}{c}\text { Rail } \\
\text { Billion TKM }\end{array}$ & $\begin{array}{l}\text { \% } \\
\text { Share }\end{array}$ & Billion TKM & $\begin{array}{l}\text { \% } \\
\text { Share }\end{array}$ & Billion TKM \\
\hline $\mathbf{1 9 7 0}$ & 127 & $66 \%$ & 67 & $34 \%$ & 194 \\
\hline $\mathbf{1 9 8 0}$ & 158 & $62 \%$ & 98 & $38 \%$ & 256 \\
\hline $\mathbf{1 9 9 0}$ & 243 & $46 \%$ & 289 & $54 \%$ & 532 \\
\hline $\mathbf{2 0 0 0}$ & 316 & $39 \%$ & 494 & $61 \%$ & 810 \\
\hline $\mathbf{2 0 0 5}$ & 442 & $40 \%$ & 659 & $60 \%$ & 1101 \\
\hline $\mathbf{2 0 1 0}$ & 626 & $41 \%$ & $944^{1}$ & $59 \%$ & 1570 \\
\hline CAGR 1970-2010 & $4.06 \%$ & & $6.84 \%$ & & \\
\hline CAGR 1990-2010 & $4.85 \%$ & & $6.10 \%$ & & \\
\hline
\end{tabular}

${ }^{1}$ extrapolation done by Author

Data Source : Annual Reports, Rail: Ministry of Railways, Road: Ministry of Road Transport and Highways 
Table 3. Trend in coastal freight transport capacity

\begin{tabular}{|c|c|c|}
\hline \multirow[t]{2}{*}{ Year } & \multicolumn{2}{|c|}{ Coastal } \\
\hline & Ships & G.T. \\
\hline 01-04-1971 & 66 & 230,822 \\
\hline 01-04-1981 & 59 & 249,633 \\
\hline 01-04-1991 & 163 & 523,733 \\
\hline 01-04-2001 & 316 & 697,242 \\
\hline 01-04-2010 & 678 & 999,430 \\
\hline 31-03-2011 & 722 & $1,024,674$ \\
\hline CAGR 1971-2011 & $6.16 \%$ & $3.80 \%$ \\
\hline
\end{tabular}

Source: Expert Group, on ports and shipping for the national transport development policy committee, (NTDPC, 2014).

Table 4. Population wise transitions in India Cities - Past and Future

\begin{tabular}{|c|c|c|c|c|c|}
\hline \multirow{2}{*}{$\begin{array}{l}\text { Size Category } \\
\text { (population) }\end{array}$} & \multicolumn{5}{|c|}{ (\% of urban population) } \\
\hline & 1975 & 2000 & 2011 & 2025 & $2050^{1}$ \\
\hline Category $1>10$ million & 0 & $15.49 \%$ & $7 \%$ & $21.37 \%$ & $21.20 \%$ \\
\hline 5-10 million & $11.30 \%$ & $5.96 \%$ & $9.57 \%$ & $4.50 \%$ & $1.3 \%$ \\
\hline Category 3 & $13.70 \%$ & $11.65 \%$ & $15.76 \%$ & $19.50 \%$ & $21 \%$ \\
\hline Category 4 & $75.00 \%$ & $63.80 \%$ & $67.3 \%$ & $54.63 \%$ & $56.5 \%$ \\
\hline Urban Population (Million) & 132.70 & 291.58 & 384.00 & 542.19 & 875.38 \\
\hline
\end{tabular}

1 Category wise break for 2050 assumes that slowdown in population growth rate would be similar across all four categories

Data Source: Historical and category wise projections till 2025 (UNPD, 2012). 2050 overall population (UNPD, 2012).

Table 5. Trip Rates, Trip Length (km) for future

\begin{tabular}{|c|c|c|c|c|c|c|c|}
\hline \multirow{2}{*}{\multicolumn{2}{|c|}{$\begin{array}{l}\text { City Category } \\
\text { (population) }\end{array}$}} & \multirow{3}{*}{$\begin{array}{c}2011 \\
\text { Trip Rate } \\
1.7\end{array}$} & \multirow{3}{*}{$\begin{array}{c}\text { Trip } \\
\text { length } \\
11\end{array}$} & \multirow{3}{*}{$\begin{array}{c}2025 \\
\text { Trip Rate } \\
2.2\end{array}$} & \multicolumn{3}{|c|}{2050} \\
\hline & & & & & $\begin{array}{l}\text { Trip } \\
\text { length }\end{array}$ & Trip Rate & $\begin{array}{l}\text { Trip } \\
\text { length }\end{array}$ \\
\hline Category 1 & $>10$ million & & & & 12 & 2.4 & 12 \\
\hline Category 2 & 5-10 million & 1.6 & 9 & 2 & 10 & 2.4 & 10 \\
\hline Category 3 & 1-5 million & 1.5 & 5 & 1.9 & 6 & 2.3 & 9 \\
\hline Category 4 & 0.5-1 million & 1.2 & 3 & 1.8 & 5 & 2.3 & 6 \\
\hline
\end{tabular}


Table 6. Trends in Household Size

\begin{tabular}{ccc}
\hline Year & \multicolumn{2}{c}{ Average Size of Household } \\
\hline $200 *^{*}$ & Rural & Urban \\
\hline 2005 & 5.40 & 5.10 \\
2010 & 5.23 & 4.80 \\
2015 & 5.06 & 4.52 \\
2020 & 4.90 & 4.25 \\
2025 & 4.75 & 4.00 \\
2030 & 4.60 & 3.76 \\
2035 & 4.45 & 3.54 \\
2040 & 4.31 & 3.33 \\
2045 & 4.18 & 3.13 \\
2050 & 4.04 & 2.95 \\
\hline
\end{tabular}

Table 7. Vehicle Technologies Defined in ANSWER MARKAL

\begin{tabular}{|l|l|}
\hline Vehicle Category & Technology Option \\
\hline 2 wheeler & Battery Electric Vehicle, Gasoline \\
\hline 3 wheeler & Battery Electric Vehicle, Gasoline, CNG \\
\hline 4 wheeler & $\begin{array}{l}\text { Gasoline, CNG, Diesel, Battery Electric Vehicle, Hybrid } \\
\text { Gasoline, Hybrid Diesel, Fuel Cell Electric Vehicle, Ethanol- } \\
\text { Gasoline blended, Bio-diesel blended }\end{array}$ \\
\hline Bus & $\begin{array}{l}\text { CNG, Diesel, Battery Electric Vehicle, Hybrid Gasoline, } \\
\text { Hybrid Diesel, Fuel Cell Electric Vehicle, Bio-diesel blended }\end{array}$ \\
\hline HCV & CNG, Diesel, Hybrid Diesel, Bio-diesel blended \\
\hline LCV & CNG, Diesel, Hybrid Diesel, Bio-diesel blended \\
\hline
\end{tabular}




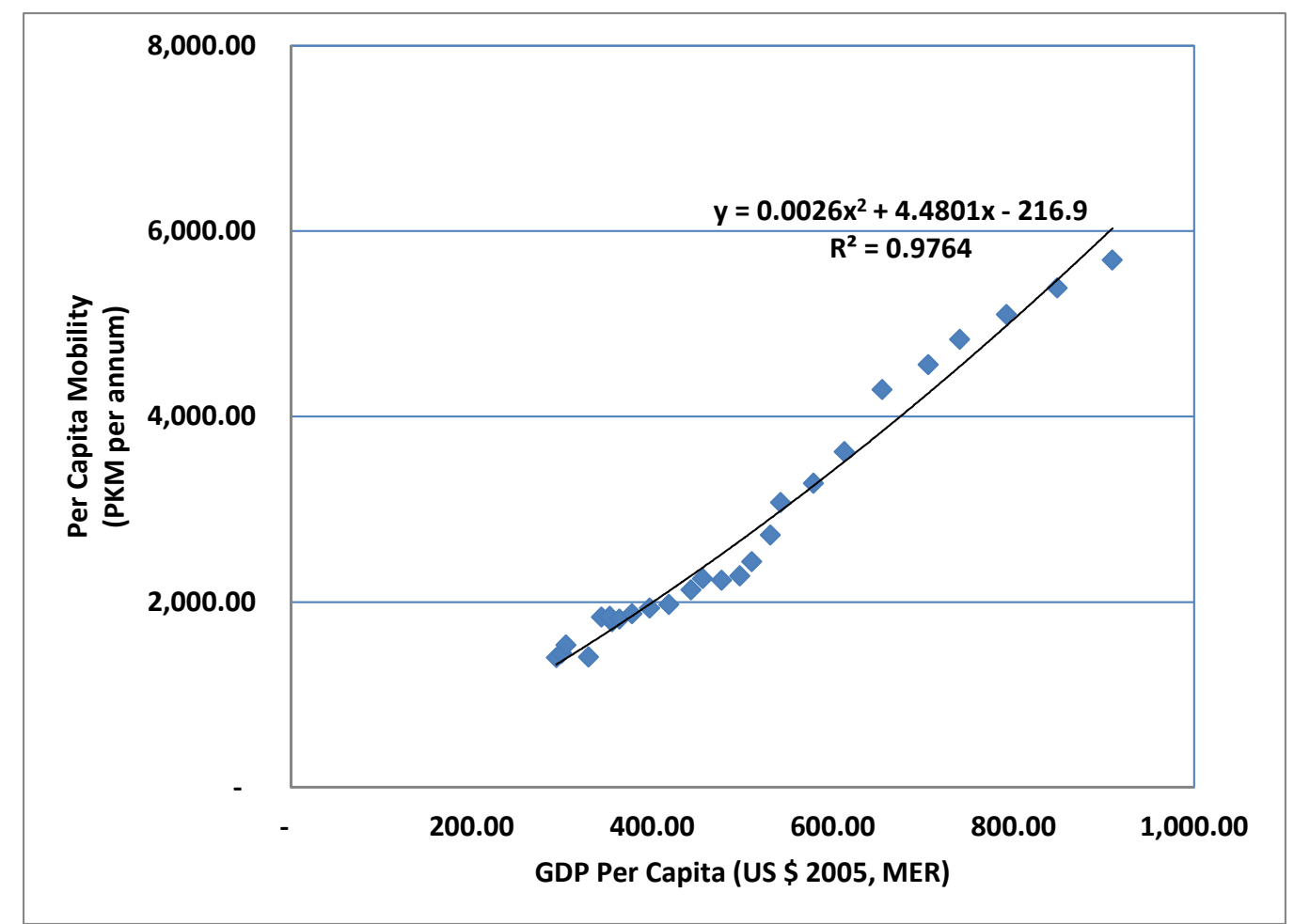

Figure 1.

Correlation of motorised per capita mobility with per capita GDP (MER in 2005 US \$) using data from 1980 to 2010

Data: Population (UNPD, 2013), GDP (WB, 2014) and Mobility (Data Source provided in Table 1)

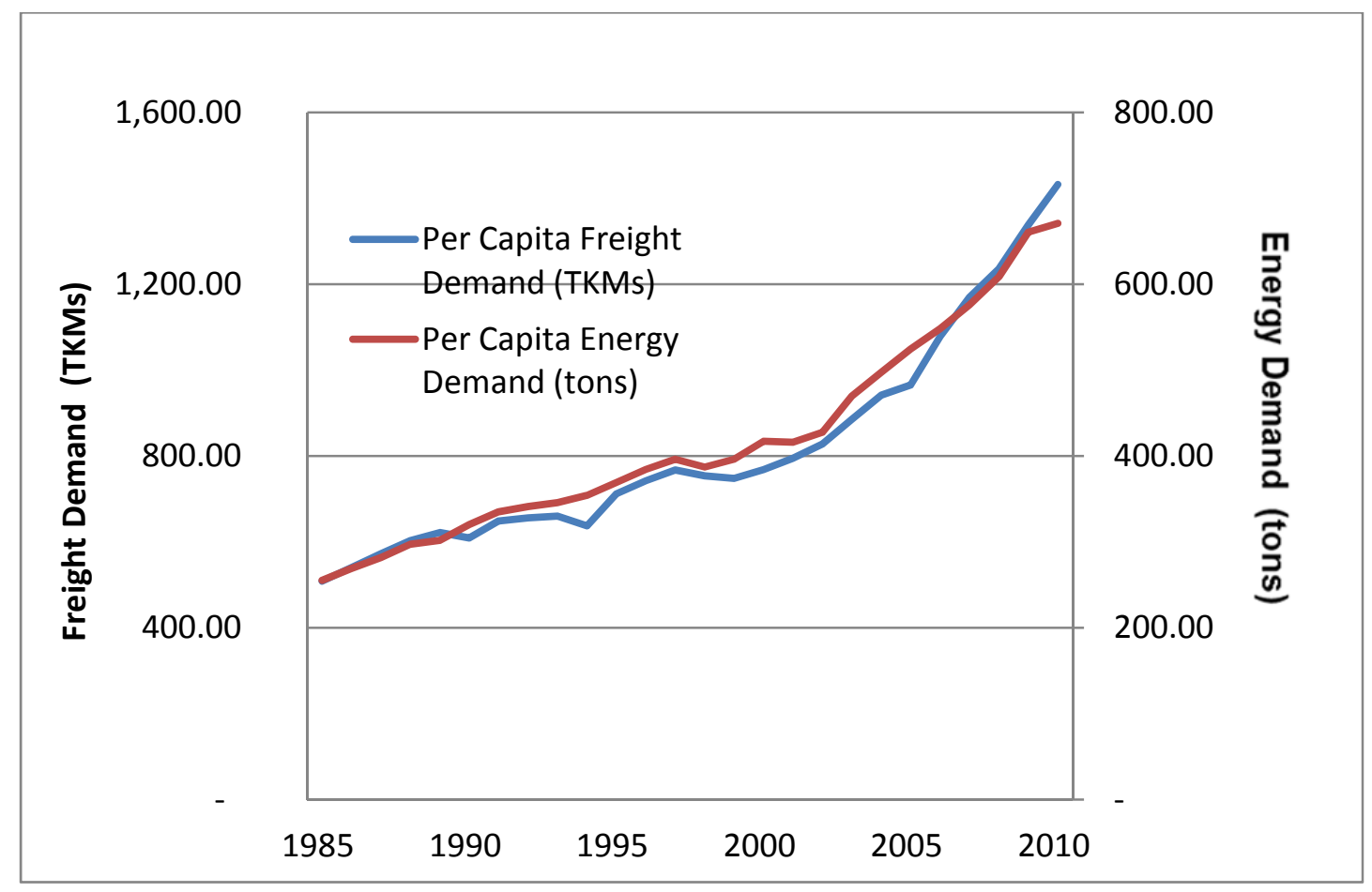

Figure 2.

Per Capita Freight Demand Vs Energy Demand

Data: Population (UNPD, 2013), Energy (CMIE Database) \& Freight (Data Source provided in Table 2) 


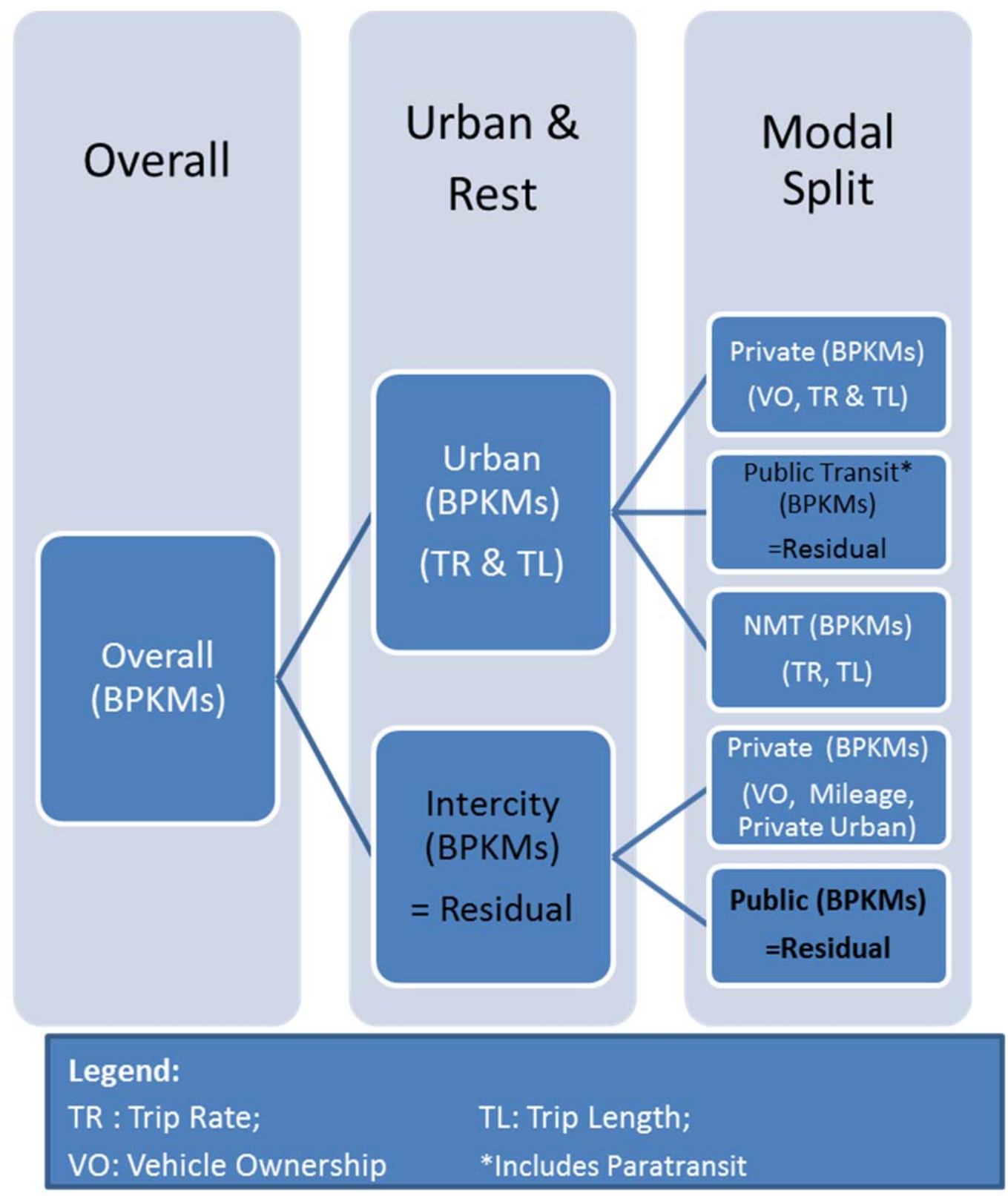

Figure 3.

Methodology for estimating passenger demand 


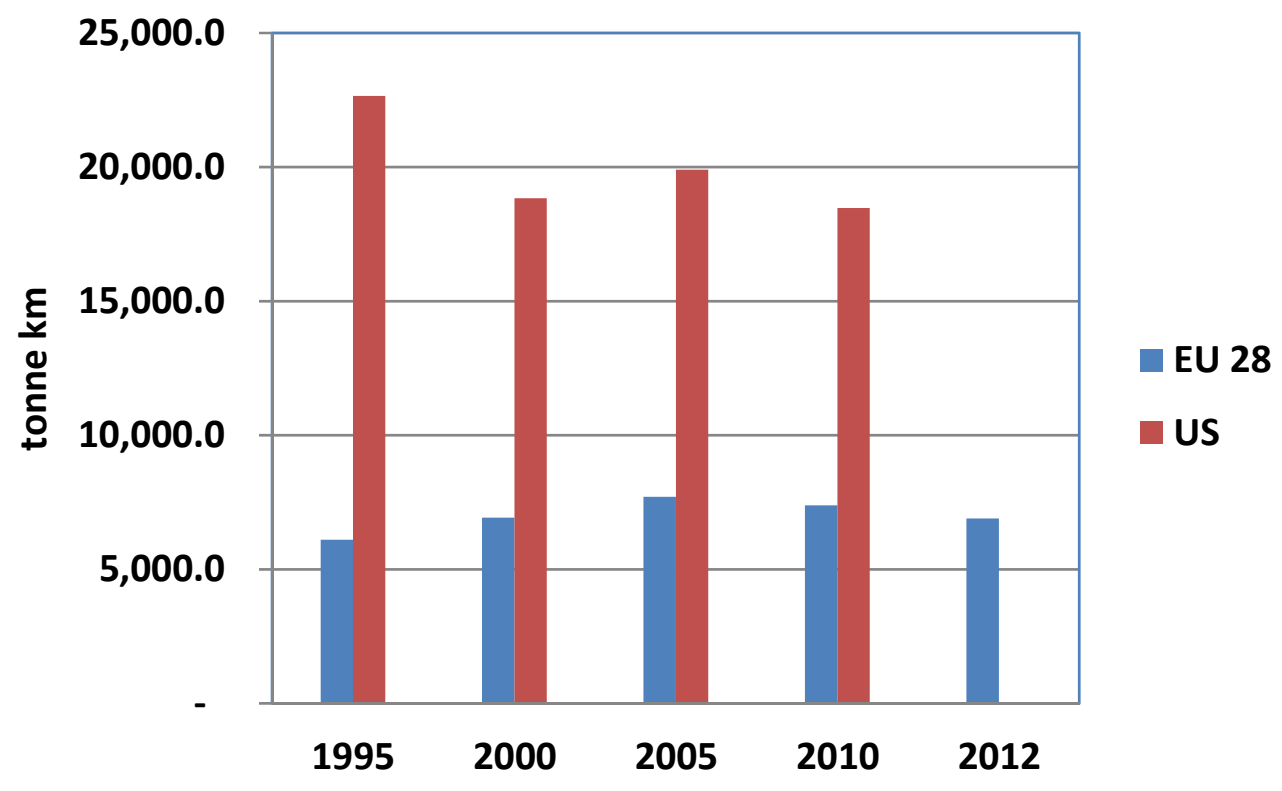

Figure 4. Average Per Capita Freight Demand (tonne km) in EU 28 and US

Source: Data for EU 28 from (EEA,2013 for freight data \& EC, 2013 for population) and USDoT, 2014 for US

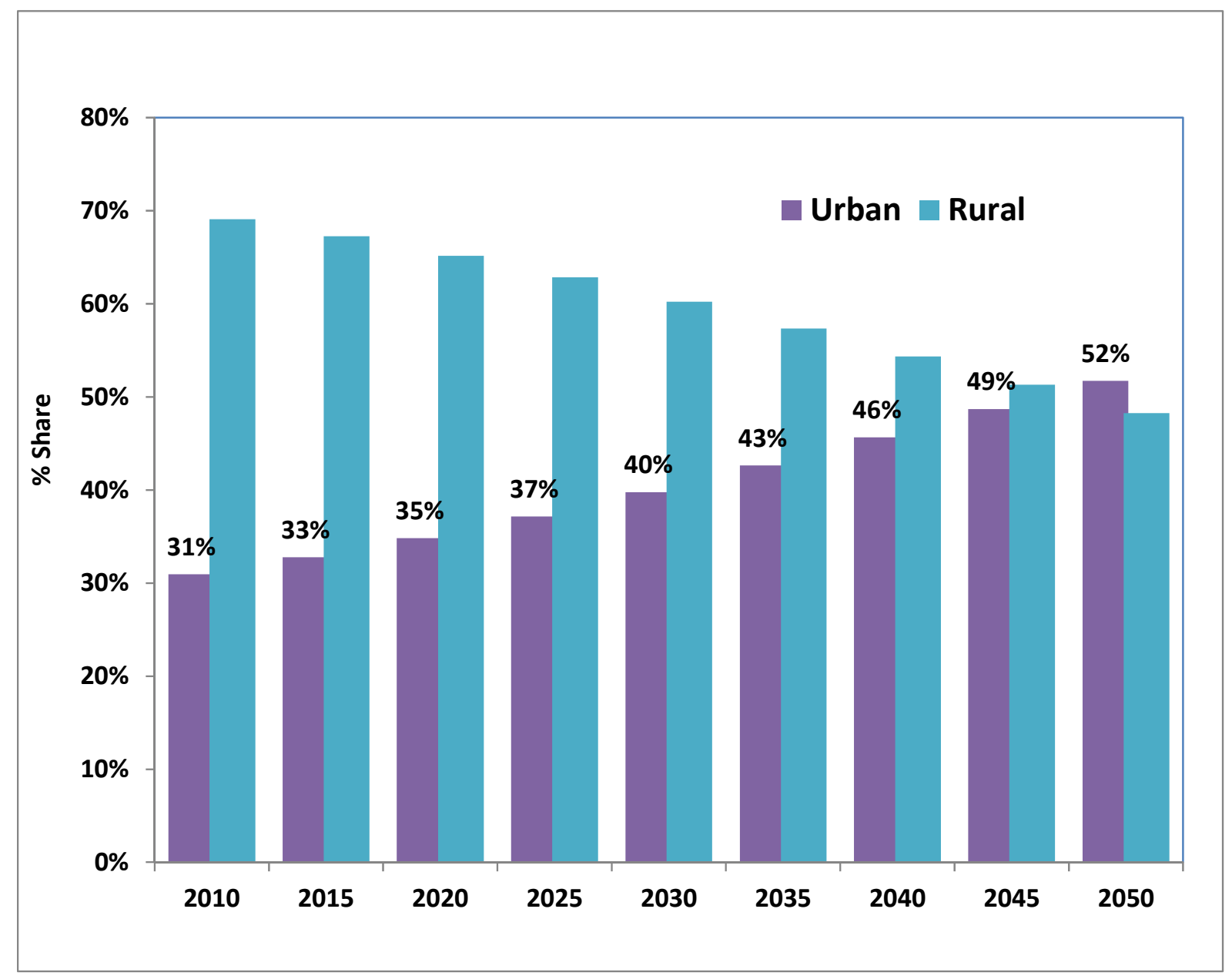

Figure 5.

Rural and urban population transitions of India in BAU

Source: Data from UNPD, 2013 

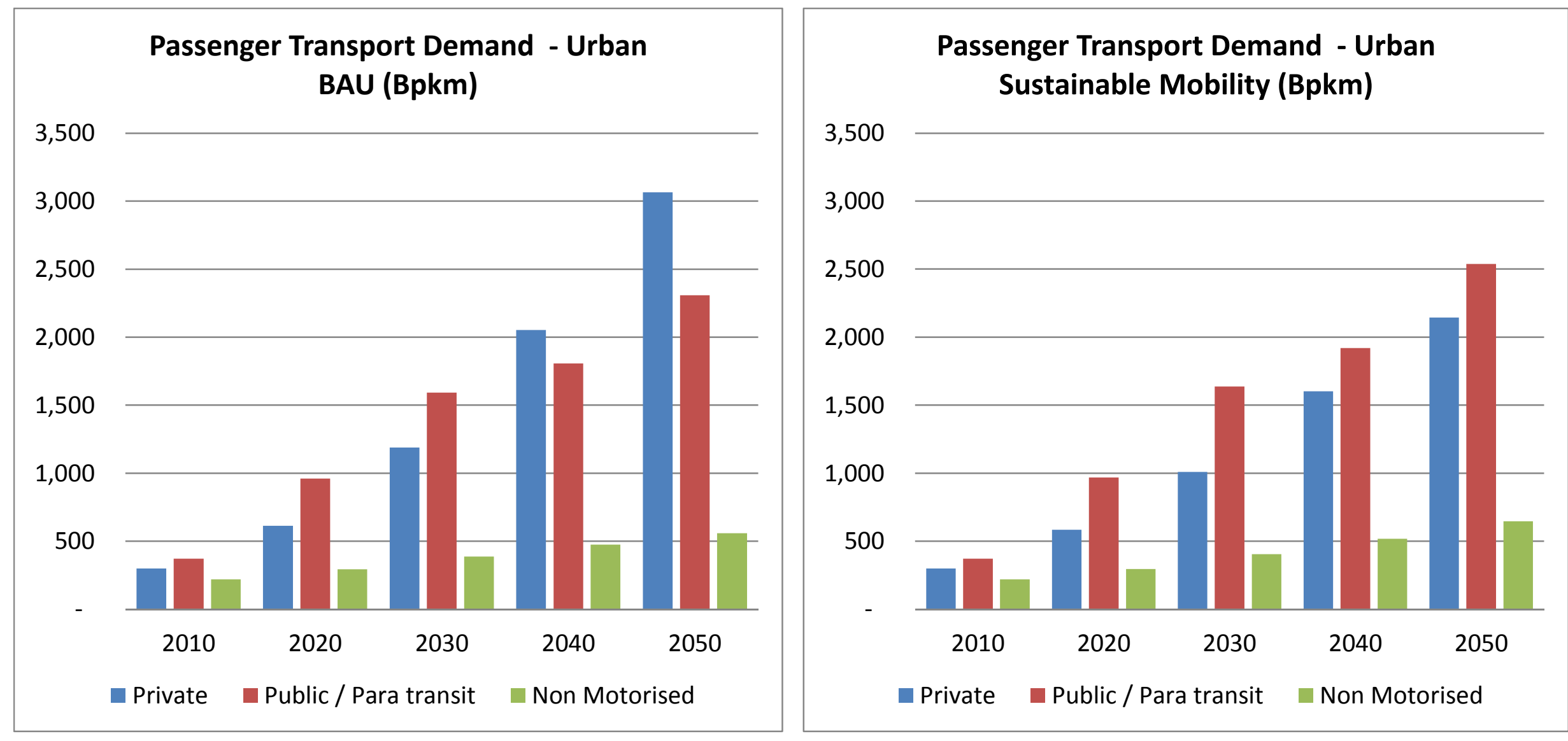

Figure 6.

Passenger Transport Demand Urban Transport: BAU \& SLCT Scenario 

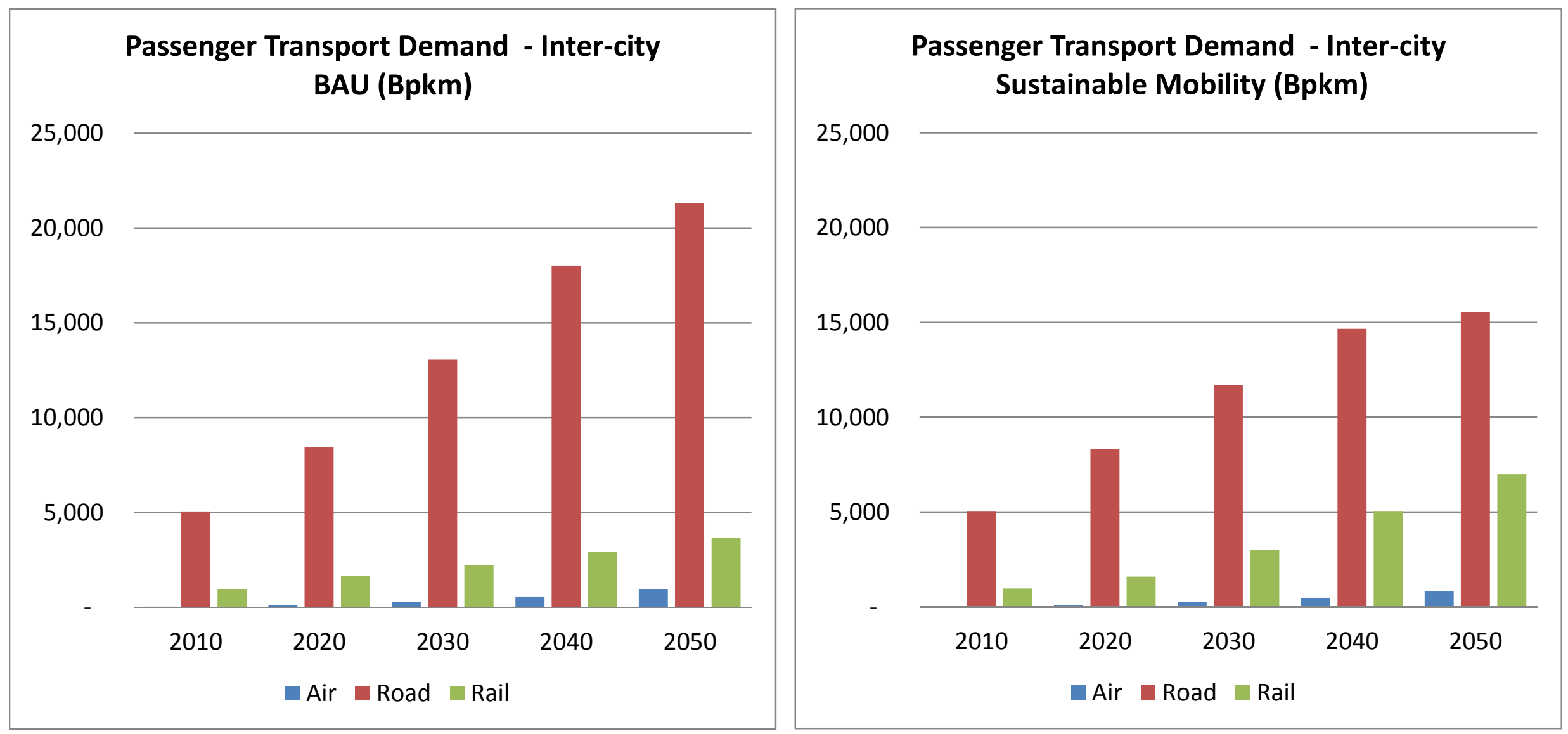

Figure 7.

Passenger Transport Demand Inter-City Transport: BAU \& SLCT Scenario 


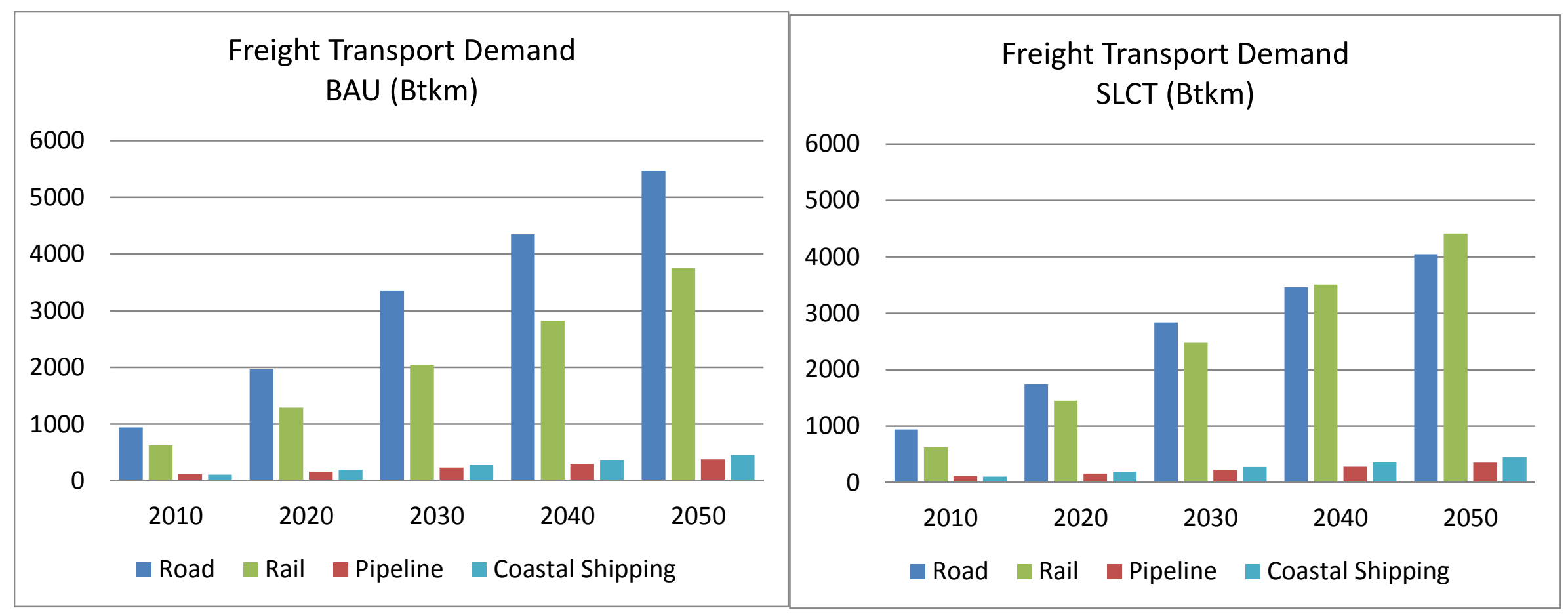

Figure 8.

Freight Transport Demand: BAU \& SLCT Scenario 


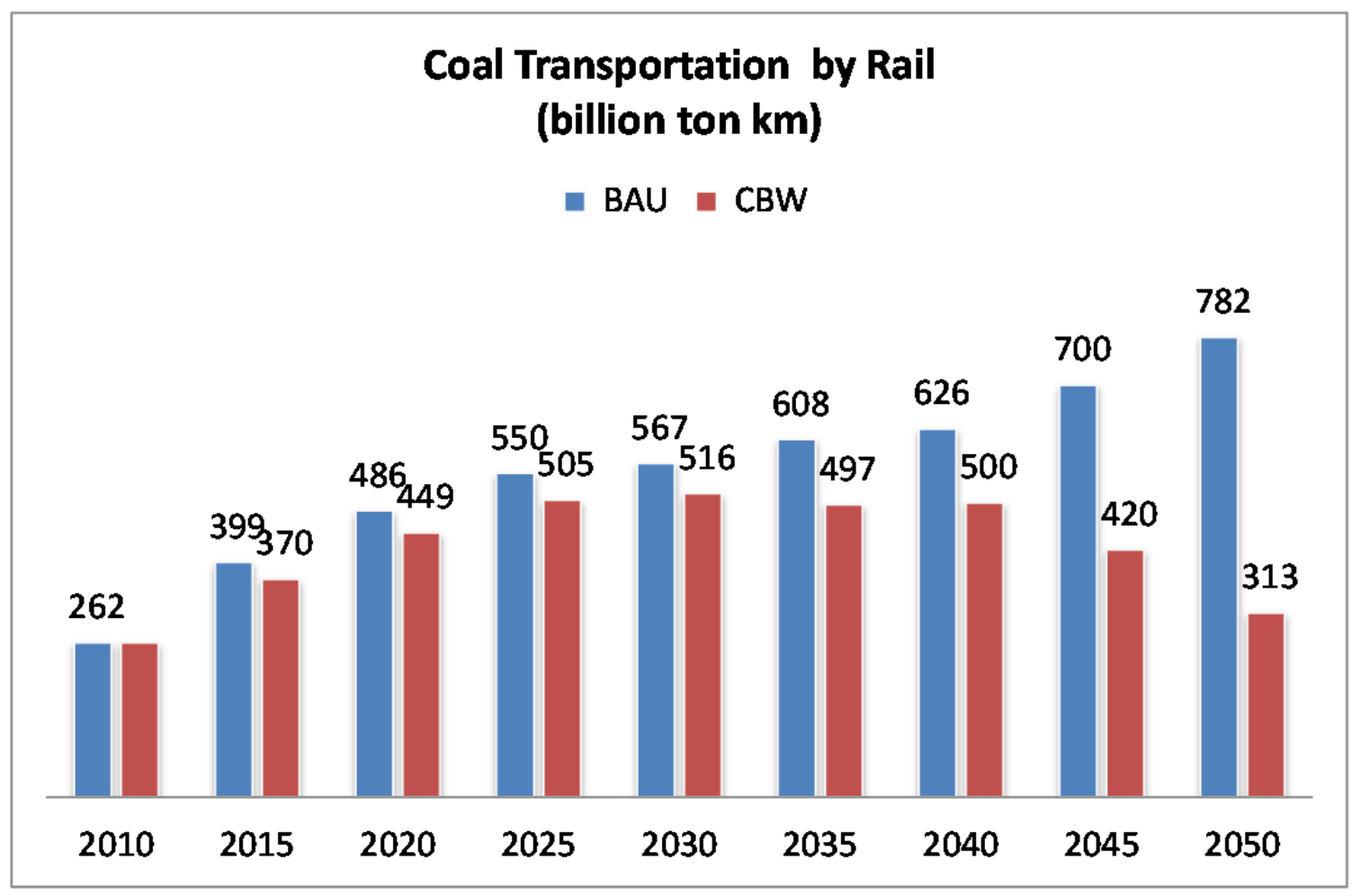

Figure 9.

Demand for coal transportation by rail: BAU and SLCT Scenario 


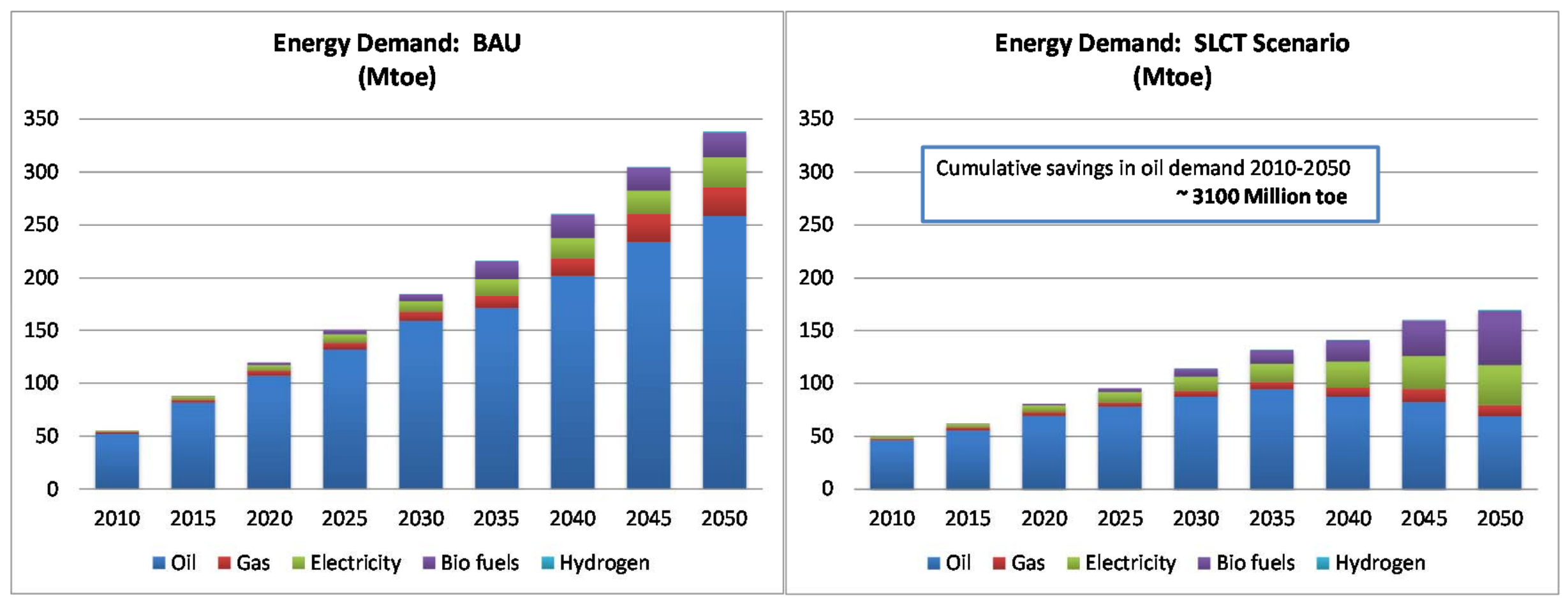

Figure 10. Energy Demand for transport: BAU \& SLCT Scenario (excluding demand for bunker fuels) 


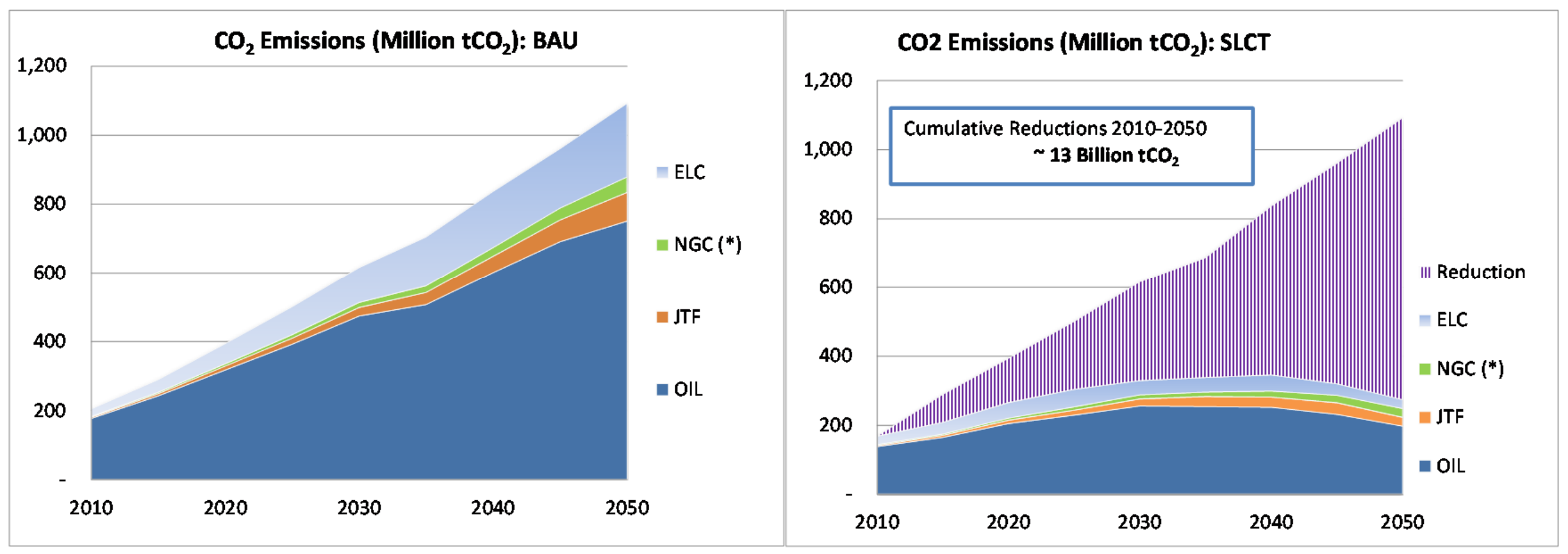

Figure 11. $\quad \mathrm{CO}_{2}$ Emissions from transport in BAU \& SLCT Scenario (Includes embedded CO2 emissions from electricity use) 


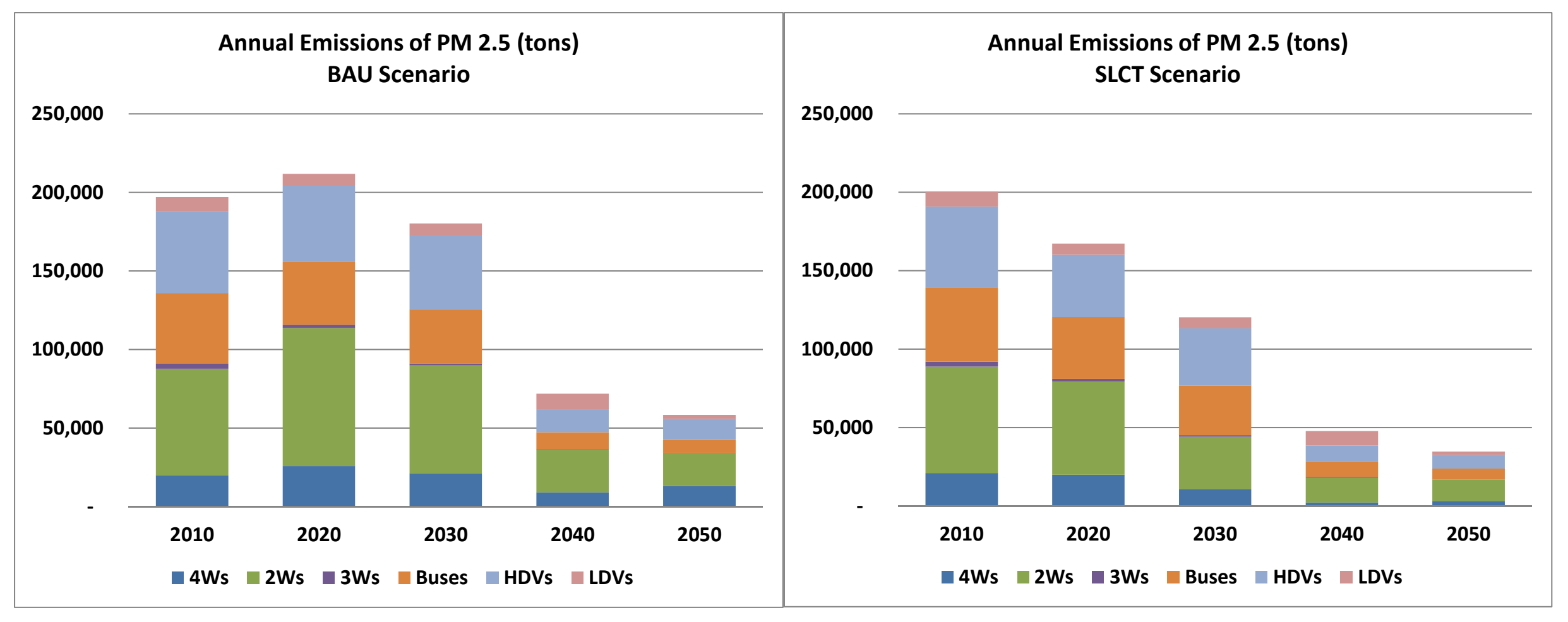

Figure 12. PM 2.5 Emissions in BAU \& SLCT Scenario 


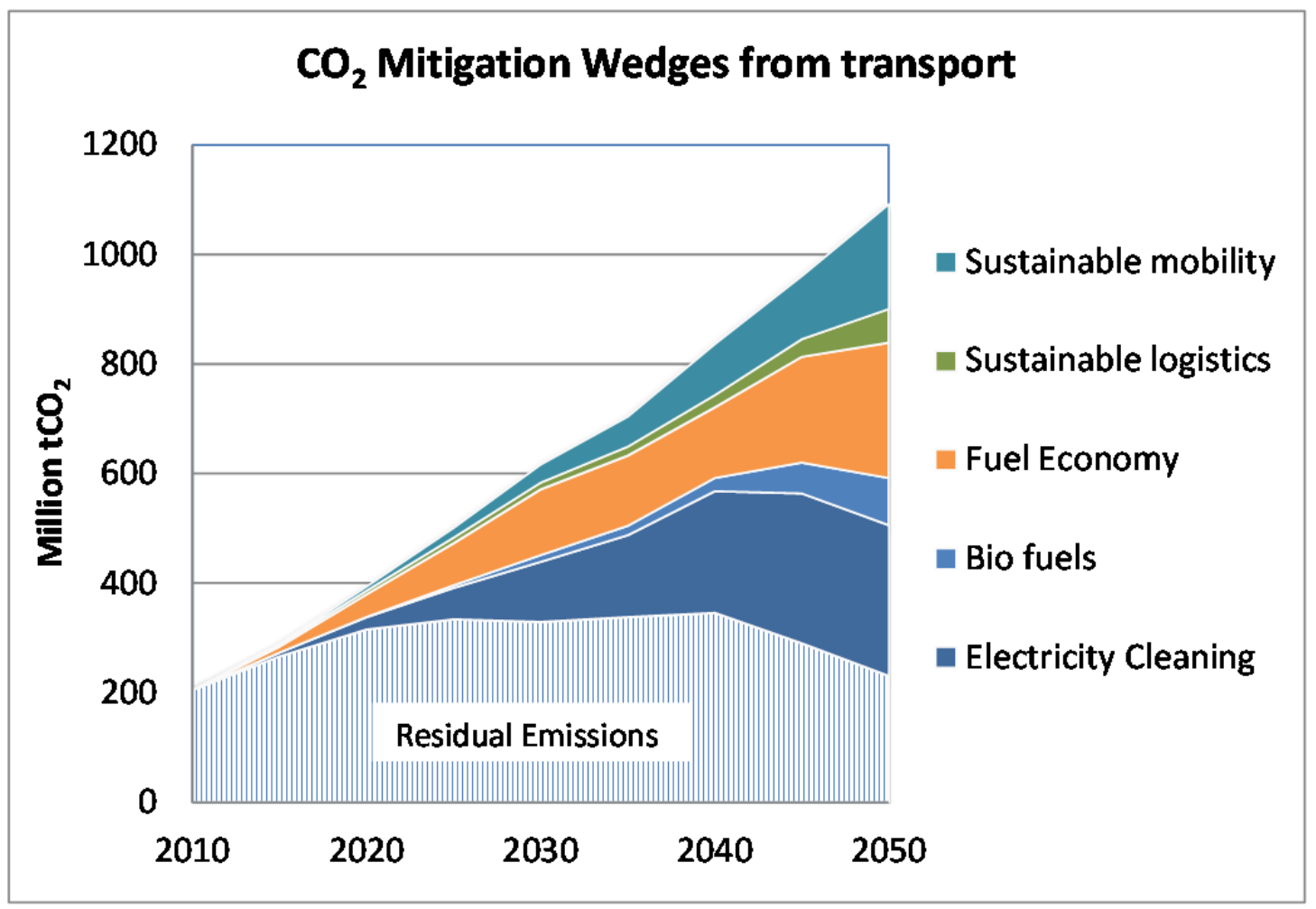

Figure $13 . \quad \mathrm{CO}_{2}$ Mitigation wedges from transport 